\title{
Topic C: Environmental and Metabolism
}

\section{Environmental Fate}

（社）日本植物防疫協会研究所 高橋義行

Topic Cの各セッションの中で最初にスタート（平成 11 年 10 月 25 日, 10:00)した表題 (Environmental Fate)のセッショ ンについての報告を筆者が担当することになった．本セッショ ンでは, Dr. Joel R. Coats（アイオワ州立大学）と山本広基氏 (島根大学) が session organizer となって運営され, 筆者の演題 を含めて 4 題の招待講演が行われた．本報告ではこれらの講演 の順にしたがってその内容（概略）について可能な限り紹介す る.

なお, 日本農薬学会の関係者には本会議への出席に際して, また山本氏と加藤保博氏 (残留農薬研究所) には講演に際して, それぞれ多大なるご指導・ご鞭撻を頂いた。この場を借りて御 礼申し上げる，また，日植防研究所の同僚・諸兄および事務局 の関係者の心からのご支援に深謝申し上げる.

1. Development of an Indoor Model Test for Runoff (筆者) これは, 屋内の小規模地表流出試験系の開発についての講演 である．近年，投下農薬の地表流出による水系污染が懸念され るようになったが，日本では個々の畑地の面積は小さく，しか も異なる作物が入り交じって栽培されているため，個々の固場 からの流出量を把握することが求められた。しかし，実戋場を 用いて実験的に流出を観察することはきわめて困難であった. このため, 大型コンテナ $\left(0.7 \mathrm{~m}^{2}, 0.73 \mathrm{~m} \times 0.93 \mathrm{~m}\right.$, 深さ $\left.0.2 \mathrm{~m}\right)$ に圃場の表層土壤 (黒ボク土壌)を詰込んだ小試験区を作成し, 降雨量を容易に制御することが可能な人工降雨装置（有効降雨 範囲： $1.04 \mathrm{~m}^{2}$ ) の下に角度 $5^{\circ}$ の傾斜をつけて設置して, 屋内で の小規模地表流出モデル試験系を開発した。 まず，自然降雨に よって野外圃場で発生した地表流出を本試験系で再現できるか どうかを検討した。 その結果, 降雨強度と降雨時間を人工降雨 装置で再現することで, $0.7 \mathrm{~m}^{2}$ の試験区から圃場 $\left(840 \mathrm{~m}^{2}\right)$ と同 じ水流出量 $\left(l / \mathrm{m}^{2}\right)$ および水流出率が得られた。 さらに, 採取 した地表流出水中の農薬濃度および農薬の流出率を計測した結 果，固場の結果とほぼ同じ值になった。このことから本試験系 によって自然環境で発生する地表流出が再現できることを明ら かにした。 また，本試験系を用いて各降雨強度による地表流出 の条件を明らかにし，これを基にアメダス等で得られる降水量 から地表流出の発生の有無と発生水量を予測した. その結果, ある程度予測可能であったことから, 本試験系の正当性がさら に立証された。本試験系を用いたモデル試験 $(30 \mathrm{~mm} / \mathrm{hr}$ の降雨 で $1 l$ の地表流出水の採取)において, 試験区に植栽した場合と しない場合，また試験区を 2 連制で実施した場合について検討
した. その結果, 農薬の流出率には作物の有無による大きな影 響は認められなかった. また, 2 連制の試験区間での相違は作物 があった場合のほうが大きかった，したがって，本試験系を用 いた地表流出モデル試験では，無作物の試験区で少なくとも 2 連制で実施することが萀められることなどを紹介した。

2. The Lysimeter Concept-A Comprehensive Approach to Study the Environmental Behaviour of Pesticides in Agroecosystems (Dr. Fritz Fuhr: Forschungszentrum, ドイ ツ)

演者らのグループはこれまでライシメータを用いた多数の事 例の研究を実施してきており，それらの豊富な事例を用いて表 題の講演がなされた. 講演は, 以下の 4 つの項目に沿って進め られた。

- Vapor and metabolism in plant

- Volatilization, mineralization

- Translocation in the soil and leaching

- Residue situation in the soil

屋外ライシメータでの研究のために，フィールドで採取した 土垬コア (径約 $1 \mathrm{~m}^{2}$ ) を圃場に埋設し， ${ }^{14} \mathrm{C}$-ラベルを用いた Radioactivityによる農薬の長期間の動向（Mass Balance）をよ り自然に近い状態（気候，植栽および土壌条件等）で調査した ことを，事例を上げて紹介された. ${ }^{14} \mathrm{C}$-ラベルした anilazine (水 和剂）を 1985 年に 1 回目，以後 1 年間隔で 4 回，また同様に methabenzthiazuronを 3 回繰り返し散布 (冬小麦, 大麦, テン サイの輪作中の冬小麦に）したあとで，土壌と植物に残留して いる各農薬について, 土壤から抽出されない残留分も含めて紹 介された。また， mineralization/volatilization (揮発)，同様に translocation (移行)/leaching（優先的な流れと選択的な流れを 含む）研究のための実験的なアプローチについてそれぞれ紹介 された。これらの試験結果は登録要件事項の一部として利用さ れていること, さらに，一般農薬の使用方法をより実用的なも のに改良するのに利用できるのではないかと紹介されていた。 また，果樹に適用した場合，ラベルしたアイソトープは新葉と 幹の樹皮に多く集まること，果実でも表層により多くみられる ことなども紹介していた。

なお，演者らのグループはライシメータを用いた報告を他に ポスターで 5 題発表していた.

3. Predicting Behavior of Selected Herbicides in Paddy Field by Computer Simulation Model（高木和広氏：農業環境研 究所)

本題では，新規に開発された Paddy Field Model (PCPF-1) の紹介, 各入力 parameters の収集と検証を中心に講演が進めら れた. さらに, Field Monitoring (固場残留試験) 結果との比較 による PCPF-1 の評価・検証が行われた. PCPF-1 は, 田面水と 

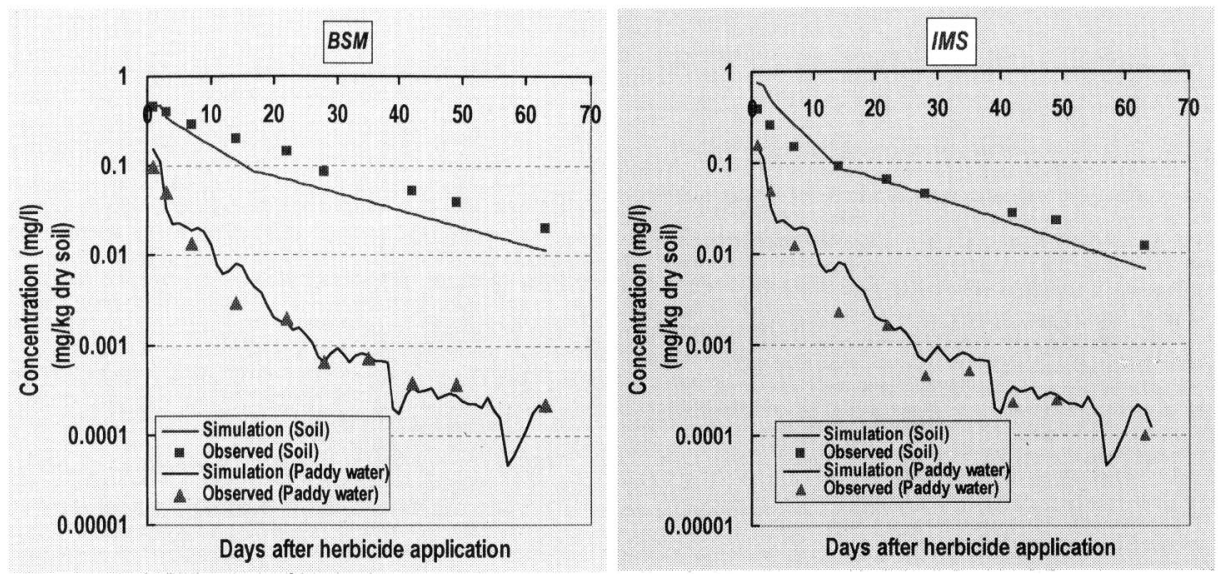

Fig. 1 Simulated and observed concentrations of $B S M$ and $I M S$ in paddy water and surface soil $(0-1 \mathrm{~cm})$ at NIAES field station in 1998 .

表層土壌 $(0 \sim 1 \mathrm{~cm})$ 中の薬郕濃度を予測するためのシミュレー ションモデルとして開発されたこと, 本モデルは田面水と表層 酸化土䁃 (水相と土相に分かれる)の 2 つのコンパートメント から成り立っていることなどが示された，また，計算には 21 項 目の入力パラメー夕と毎日の田面水水収支及び稲体下 (田面水) まで到達するUV-Bの日エネルギー量のデータファイルを必要 とする.このモデルの特徵は, (1)薬剂の土㙵中分解速度定数と 脱着速度定数が 2 フーズに設定できる, (2)田面水中での薬剤 の光分解速度が田面水（稲体下）に到達する UV-B 積算量を用 いて算出される，(3)毎日の田面水水収支デー夕が読み込まれ， 薬剤の田面水中濃度が計算される，の 3 点である．プログラム はMS-EXCEL のマクロを用いて行われている，入力パラメー 夕は野外の水田環境条件を考慮した室内モデル実験から得られ たものである。シミュレーションの結果は, Pretilachlor, Mefenacet, Bensulfuron-methyl (BSM) と Imazosulfuron (IMS) の围場残留試験のデー夕を基に評哂された（Fig. 1)。これらの 除草剂の田面水中と表層土塨中の濃度は, 新しく開発されたこ のモデルによって農薬散布後 9 週間まで, きわ力て正確に予測 可能であることなどが紹介された。

4. Fate of Pesticides in Tropical Ecosystems (Dr. Kenneth Racke: Dow AgroSciences, 米国)

本題は, 主に次の 3 つの項目を中心に講演された。

- Fate of Pesticide in Soil and Water

- Laboratory Research Study

- Field Research Study

熱带地域に打る農薬の利用は, 農業および非農業の病害虫 防除の重要な構成要素である。しかしながら, 熱带の生態系に 扩る宸薬の消長は, 温带の生態系と同じ程には理解されてい ない. 熱帯の生態系での農薬の消長等についての研究報告数は, 温帯でのと比へてて圧倒的に少ないのが現状である。温带と熱带 の生態系では農薬の消長を直接比較したほんの数例の研究では あるが，熱帯の条件下では農薬の分解がよりゆっくりになると いう証拠はない. 実験室レベルの研究では, 標準化された条件 の下では農薬の分解率と代謝は熱带と温带の土䁃と水の間で比 較できることが明らかになった。しかしながら，熱帯での農薬
消長のフィールド調查では，しばしば温带で類似した条件下で 使用された農薬よりもより迅速に消失することを示している。

一例として紹介していたのは, simazineの DT50についてであ る. 実験室レベルの試験では熱帯土壌での DT50 はほぼ温带土 㙵でのと同じ約 40 日強になり,フィールド試験では温帯土㙵で は47 日なのに対して熱帯土壌では14 日と短くなった。農薬の 消失に扔けるこの促進のための最も顕著なメカニズムは, 熱帯 の気候の影響が関係していると思われる。そしてこれには，揮 発性物質を增加させ，化学㧍よび微生物による分解率の年率 ベースを高めることを含んでいる，とのことだった。講演では 熱带土塆と温带土堙の組成は大きく異なることは少ないが, 異

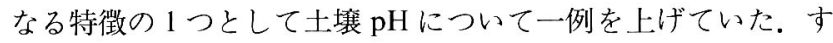
なわち，温带の日本の土壌は㧍およそ $\mathrm{pH} 6$ 7 の狭い範囲に納 まるのに対して，熱帯のタイの土㙵は $\mathrm{pH} 5 \sim 8$ と幅が大きいと いう例を上げて紹介していた。

\section{Metabolism}

\section{残留農薬研究所 佐藤 清}

Topic C: Environmental and Metabolismの内の代謝セッショ ンは講演初日の午後に開催され, 以下の 5 題の講演が行われた。 ここでは最初の 2 題を中心に報告したい.

1. Oxidative Metabolism of Pesticide In Mammals Including Human (R. L. Rose, North Carolina State University, USA) 動物実験で認められた発がン性デー夕をヒトに外挿して残留 農薬のリスクを評偳する場合, デラニー条項の存在は大きな ネックであった。この問題は1996 年に施行された Food Quality Protection Act (FQPA) により解決されたが，FQPA では combined risk assessment や幼児に対する安全係数の追加等の 様々な概念が新たに導入された，毒性メカニズムが同じ化合物 は一緒に評価するという“リスクカップ”の概念もその一つで あるが，一方で毒性メカニズムが詳細に明らかにされれば安全 係数を減らすことも可能である. 
これを検証する指標の1つとしてクロロアセトアミド系除草 剤を選んだ. Alachlor は, EPAによりヒトへの潜在的な発癌物 質として分類されている化合物であり，MTDレベルで投与し た時はラットで鼻の腫瘍を起こす.その原因は, alachlor がチト クロームP450による代謝で先ず alkoxyalkyl 基が脱離して CDEPA となり，次いで arylamidaseにより chloroacetanilide 基がはずれて diethylaniline を生成し,このものがチトクローム P450により水酸化され, 反応性が極めて高い diethylbenzoquinone imine (DEBQI) を生ずるためである. Alachlorによる 腫瘍はマウスでは起きない.これは主に鼻部組織ミクロソーム 中の arylamidase 活性の差に起因することが明らかにされてい るが, ラット鼻部組織での diethylaniline の水酸化活性もマウス に比べて高いことが分かった。一方，サルの鼻部組織中では diethylaniline の生成量が少ないことから，ヒトにおける alachlorの発がンのリスクは低いことが示唆された. Acetochlor は, ヒト肝ミクロソームによる代謝でCDEPAに相当する代謝物 CMEPAを主に生成した。次いで各種のヒトCYPアイソ フォームによる acetochlor の代謝を調べた所, CYP2B6 と 3A4 でCMEPA 生成の活性が高かった. ラットおよびヒト肝ミクロ ソームによる alachlor と butachlor の代謝比較では, ヒト肝ミ クロソームにおける alachlor からのCDEPAの生成量はラッ トの1/10であり, butachlor からは CDEPA はほとんど生成し なかった. CYPアイソフォームによる alachlorの代謝では acetochlor と同様にCYP2B6 と 3A4 でCDEPAの生成活性が 高く,特にCYP3A4 ではラットおよびヒト肝ミクロソームとほ ぼ同じ代謝物パターンが認められた。 Metolachlor ではヒト肝 ミクロソーム, CYP2B6, 3A4 いずれにおいても CMEPA は生 成しなかった（ラット肝ミクロソームでは僅かに検出）。一方, CDEPA（またはCMEPA）以降の代謝反応に関与する arylamidase と aniline hydroxylase の活性は 4 種類のクロロア セトアミド系除草剤いずれについてもヒトとラットの肝ミクロ ソームの間で差は認められなかった. ヒトの鼻部組織ミクロ ソームとラットおよびマウスのそれとの比較は研究中である. 以上のように metolachlor, alachlor と butachlor に関しては七 トの肝ミクロソームによる CDEPA（または CMEPA）の生成 能はレットと比べて低かった。このことから，発ガン性リスク に関しては alachlorよりも acetochlorの方が大きく, metolachlor と butachlorについては無視しうるものと推察された.すな わち, クロロアセトアニリド系除草剤に関しては, 同じリスク カップで評価できないかもしれない.

なお，哺乳動物における主要な酸化酵素であるチトクローム P450 とフラビン含有モノオキシゲナーゼ (FMO)の遺伝子につ いては，前者では今までに 500 以上が決定され，少なくとも 14 の遺伝子群を持つCYP 超遺伝子群を構成している. ヒト肝ミ クロソーム中に多く存在するCYPアイソフォームは CYP3A4, 2C9 と 2A6 である.一方, FMO は哺乳動物では 5 種 類が知られているのみである $(\mathrm{FMO1}$ FMO5). しかし, FMO は性差や組織間の差, 個体の成熟度等による差がそれぞれに大 きく注目される，有機リン剂 phorate の代謝をヒト CYPsとマ ウス FMOs で調べたところ，CYP2C19 と FMO3による代謝 (スルホキシドへの酸化) 活性が大きかった。
2. Molecular Genetics of Carbaryl and Fenitrothion Degradation by Soil Bacteria (M. Hayatsu, Shizuoka University, Japan)

フェニトロチオンやカルバリルは土㙋への数回の使用で分解 能を獲得した細菌が出現することが知られている. 土壌生態系 における分解能獲得過程を明らかにするため, 両化合物の分解 菌を農地土壌から分離した. 先ず, カルバリル分解菌である Blastobacter sp.M501, Arthrobacter sp.RC100, Sphingomonas sp.SB100 からカルバリル加水分解酵素を精製し, 精製酵素の特 徵の比較からそれらの相違点と類似点を明らかにした。Blastobacter sp.M501 と Sphingomonas sp.SB100はカルバリルをコ メタボリズムにより加水分解した. しかし 1-ナフトールの資化 能はなく，1-ナフトール資化菌との共生的分解が示唆された. Blastobacter sp.M501のカルバリル加水分解酵素は $35 \mathrm{~kb} の フ ゚$ ラスミドにコードされていた，塩基配列を決定した結果，2218 塩基 (766 個のアミノ酸に対応) のオープンリーディングフレー ムが認められた。これは, SDS-PAGEで分析した精製タンパク の分子量とほぼ一致した. Arthrobacter sp.RC100はカルバリル 資化能を有していた。この細菌は3つのプラスミド（pRC1， $\mathrm{pRC} 2, \mathrm{prC} 3)$ を持ち, その内の 2 つがカルバリルの分解に関与

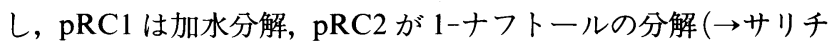
ル酸 $\rightarrow$ ゲチジン酸経路）に関与していた。なお，ゲンチジン 酸の代謝系は染色体上にあると推定された。

フェニトロチオン資化能を有するBurkholderia sp.NF100 は, そのリン酸結合を加水分解して3-メチル-4-ニトロフェ ノ一ルを生成し，これをさらにメチルヒドロキノン経由で代謝 した。 NF100株は 2 個のプラスミド (pNF1 と pNF2)を持って いた。キュアリング実験(プラスミド除去)により pNF1はフェ ニトロチオン加水分解酵素をコードし, pNF2 はメチルヒドロ キノン代謝系をコードしていることが分かった.フェニトロチ オン加水分解酵素遺伝子をコードする $13 \mathrm{~kb}$ の DNA 断片を詳 細に解析したところ, 加水分解酵素は 3 つの ORF を含む $6 \mathrm{~kb}$ の断片にコードされていた。 また，メチルヒドロキノンの芳香 環開裂に関与寸るオキシゲナーゼ遺伝子のクローニングを行 い， $5 \mathrm{~kb}$ の塩基配列を決定したところ，2,4-DCP モノオキシゲ ナ一ゼおよびカテコール 2,3-ジオキシゲナーゼと相同性のある ORF が認められた。これらの結果は, 土壌において細菌間でプ ラスミドの水平伝達が起こり, 分解菌が出現する可能性を示唆 するものである.

3. A Functional Genomics Approach to the Enzymes of Plant Xenobiotic (D. P. O'Keefe, DuPont, USA)

高等植物においては, 大部分の農薬は 2 種類の遺伝子群の産 物であるチトクローム P450 とグルタチオン S-トランスフェ ラーゼ（GSTs）により代謝される．DNA の塩基配列を決定す ることにより，これらの遺伝子群を構成する多数の分子種が明 らかにされてきたが，塩基配列に基づいて個々のP450または GST の異物代謝における特異的な役割を確認するための背景 となる情報は不十分である，個々の遺伝子産物の役割を分析す るため, 2 種類の遺伝子群の特性を明らかにすることを試みた。 例えば，GST 活性が高いトウモロコシ (maize) の組織から全て の mRNA を集め, クローニングにより cDNA ライブラリーを 
作り，既存のデータベースを利用してそれらの塩基配列と既知 の GST の遺伝子配列との類似性を比較することにより, maize に固有な 41 の GST を認めた. Maize とダイズの GST 遺伝子は 4 種類の群に分けることができた。これらは大腸菌により容易 に発現させることが可能であり, 様々な基質 (chlorimuron ethyl, alachlor, atrazine, CDNB, ethacrinic acid 等) に対する活 性を分析し，比較することができた. GSTs の特徴として，遺伝 子配列に基づく分類と活性との相関はほとんどなく, 多くの酵 素でいずれの基質に対しても何らかの活性が認められた，同様 にして調べたP450 遺伝子に関しては Arabidopsis で約 350 の 分子種を認めた。遺伝子配列に基づく分類と基質に対する活性 には若干の相関か認められた。実験に用いた基質に対して 1 種 類の酵素のみが高い活性を示し，その他の酵素では活性は認め られなかった。

4. Metabolism of Ethaboxam in Soil (J-H Kim, Soel National University, Korea)

韓国の LG Chem 社で開発された殺菌剤 ethaboxam の好気

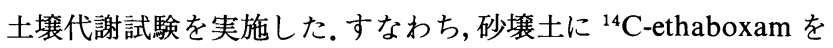
$0.372 \mu \mathrm{gg}^{-1}$ の濃度で施用し, 通気捕集システム中で最長 60 日 間インキュベートした。各試料採取時点における物質収支は 94\% 101\%の範囲であり， ${ }^{14} \mathrm{C}$-ethaboxam の DT50 と DT90 は それぞれ 17 日および 53 日であった。主代謝物である AMETC

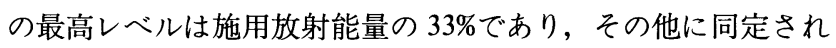
た 3 種類の代謝物（ETC, ETTC, ETCA）の最高レべルは，そ れぞれ $10 \%, 7 \%$ およ゙ $2 \%$ であった. ${ }^{14} \mathrm{CO}_{2}$ 発生量は処理 60 日後

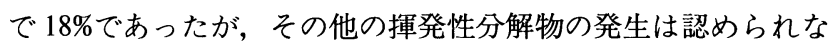
かった. 有機溶媒で抽出不可能な ${ }^{14} \mathrm{C}-$ 残留物は 60 日後で施用 放射能量の $38 \%$ に達し, その大部分 (68\%) はヒューミン画分中 に分布していた。

5. Translocation and Metabolism of Pesticides in Rice Plants with Nursery Box Application (S. Kurogochi, Nihon Bayer Agrochem K. K., Japan)

苗箱処理は, 稲作における労力軽減と低環境負荷に資する処 理法として, 現在までに浸透性を有する 12 種類の殺虫剤, 10 種 類の殺菌剤について適用が検討中（または適用済み）である。 水稲用の殺蝓イミダクロプリドと殺菌剂カルプロパミドの水 稲における代謝試験を，苗箱処理を模した施用法を用いて実施 した。 [メチル $\left.-{ }^{14} \mathrm{C}\right]$ イミダクロプリドを $0.32 \mathrm{~kg}$ a.i./ha で施用 した後, 登熟期（処理 124 日後）まで栽培した。放射性綕残留 物（TRR）は, 青刈り（処理 65 日後）で $0.38 \mathrm{mg} / \mathrm{kg}$ であり, 登熟期における稲わらと玄米中の TRR はそれぞれ 1.31 および $0.014 \mathrm{mg} / \mathrm{kg}$ であった. 代謝物は GC-MS, FT-NMR およびコク ロマトグラフィーで同定し, 水稲中でのイミダクロプリドの代 謝経路を明らかにした，玄米中の TRRの 60\%は天然成分(放射 性デンプン）で構成されていた，イネ幼苗を用い，水耕法によ

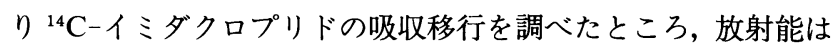
速やかに全身に移行したが, 特に葉頂部への移行が多く認めら れた. [フェニル-UL- $\left.{ }^{14} \mathrm{C}\right]$ カルプロパミドの水稲中代謝運命を 同様に調べた (施用量は $0.4 \mathrm{~kg}$ a.i./ha). 青刈り (処理 67 日後), 稲わら，玄米中の TRR はそれぞれ $0.56,1.63$ および $0.012 \mathrm{mg} /$ $\mathrm{kg}$ であり, 登熟時では放射能の 97\%以上が稲わらに存在してい た. 主代謝経路はシクロプロパン環メチル基の水酸化とそれに 続く脂肪酸および糖との抱合反応またはカルボン酸への酸化で あったが, いずれの部位でも主要残留物は親化合物（TRRの 60\%前後)であった. 水耕処理では放射能は全身に均一に分布し たが，導管部位と推定される位置への斑点状の分布も認められ た。水溶解度を超えて移行した化合物が局部的に結晶化した可 能性があり，有効成分の長い残効性への寄与が示唆された。 た だし, どちらの農薬も可食部中の残留性は低く, 安全性に優れ ることが分かった。

\section{Environmental Risk Assessment}

国立医薬品食品衛生研究所化学物質情報部 関沢 純

環境リスク評価のセッションでは以下の 6 題の発表があっ た。 セッションオーガナイザーは, カナダ Guelph 大学の Solomon 教授と韓国化学研究所の金容華博士だった.

1. トリアジン系除草剤の環境分布に関するリスク評価： Solomon, K. (Guelph 大学, カナダ)

2. 人の健康と生態系へのリスク評価：金 容華（化学研究所, 韓国)

3. 米国中西部農業地带生態系におけるクロルピリフォスの生 態学的リスク評価：Mayes, M. (Dow AgroSciences, 米国)

4. ピレスロイド系殺虫剤の水系生態リスク評価一高次レベル の段階的評価への手法：Giddings, J. (Springborn Laboratories, 米国)

5. 化学物質の統合的なリスク評価へのアプローチー環境ホル モン物質による事例研究：関沢 純（国立医薬品食品衛生 研究所, 日本)

6. 農薬処理種子および散布による果樹園の鳥類へのリスク：

Hart, A. (Central Science Laboratory, 英国)

演題の内容は生態系リスク評価，それも懪露評価に関わる発 表が多かった．環境リスク評価という主題がこの学会でこれま で多く議論されてこなかったテーマであるせいか残念ながら深 く突っ込んだ討論は見られなかった。これは特にわが国でリス ク評価が国としても的確に位置付けられておらず，研究もこれ まで強力に進められてきていないため, 日本の研究者の多くが このテーマに慣れていなかったせいかも知れない.しかし合成, 環境中動態, 天然物, 代謝, 環境リスク評価, バイオ農薬と遺 伝子操作作物, 環境化学々残留分析, 耐性（殺虫剂, 除草剂, 殺菌剂), 計算化学, 作用機作の 12 のセッションのうちの 1 つ として企画され, 寸べてで 60 題の口頭発表のうち 6 題が本セッ ションで報告されたことは, 企画された島根大学山本広基先生 のご尽力に敬意を表したい，農薬の専門家が農薬使用に関わる 環境や人の健康への影響に関わるリスクの研究を行政の問題と してでなく，毒性や耐性，環境中動態のメカニズムといった， これまで個別のテーマにおいて進めてきた研究成果の上にたっ て総合的に考察，予測，評価することの重要性に関心を持ちつ つあると考えられる。 
以下発表内容について, 当日のメモを基に個別に紹介しよう。 Solomon 教授の講演は, 生態系の環境ストレス(逆境的要因) への適応と弾力性ある対応，農薬の環境中の分布と影響におけ る分布の統計的な解析に基づく予測の話しであった. まず根圏 における硝酸態の濃度分布に反比例して生物多様性（種の数） が失われるという現象や, 生物種間での相互作用が存在するこ とから, ある農薬の環境中濃度から単純に予測される単調な影 響の大きさとは異なる影響の強さが実際には観察されることが 紹介された．さらに地域的な種の絶滅は回復可能であるが，回 復期間は死滅割合に応じて幾何級数的に永くなるという傾向が 解説された. 次に生態学的な影響評価において確率論的な扱い が重要であることから，環境リスク評価についての米国環境保 護庁やカナダのグループの予測モデルに基づいてリスク比 (Risk Quotient) という概念を紹介した. すなわち集団のある一 定割合が影響を受ける可能性をトリアジン系除草剂（アトラジ ン, シマジン, シアナジン）についての毒性データベースと, これら農薬の表層水中分布の調査結果との関係から論じこれら 農薬による水棲植物へのリスクは比較的小さいと結論した.

関沢は，国際化学物質安全性計画（IPCS）が中心となり，経 済協力開発機構 (OECD), 米国環境保護庁 (US EPA) と共同 して進めている統合的リスク評価の企画メンバーの一員として 統合的なリスク評価の意義と, 環境ホルモン物質についてのそ の応用研究例を紹介した．統合的リスク評価とは，リスク評価 のさまざまな局面で，たとえば健康影響リスクの研究者と環境 影響リスクの研究者がそれぞればらばらに研究を進めている現 状に対して, 共通の問題点の検討や共通の情報を持つことに よって背景メカニズムや，人と環境中生物に共通したリスクの 存在への理解を増し, 結果としてより正確, 効果的で現実的な 評価が可能となることを探るものである（図 1). 実際には曝露 サイド（環境分析など）と影響サイド（毒性評価など）の間の 意見や情報交換もあまり行われてこなかったのが実態であり， このためリスクの全体像を把握することが遅れ, 環境ホルモン 問題で特徵的なように理解と対応における混乱が顕著に見られ ている(表 1)、筆者は, 国内あるいは国際的な専門家グループ と協力して, 環境ホルモン物質, とりわけ植物ホルモン物質へ の曝露による日本人におけるリスクとベネフィットの詳細な分 析，および有機錫の環境中生物と人の健康への影響について影 響メカニズムと曝露の実態に基づく解析を行った結果を報告し た. 聴衆の多くがリスク評価について必ずしも深い理解を持っ

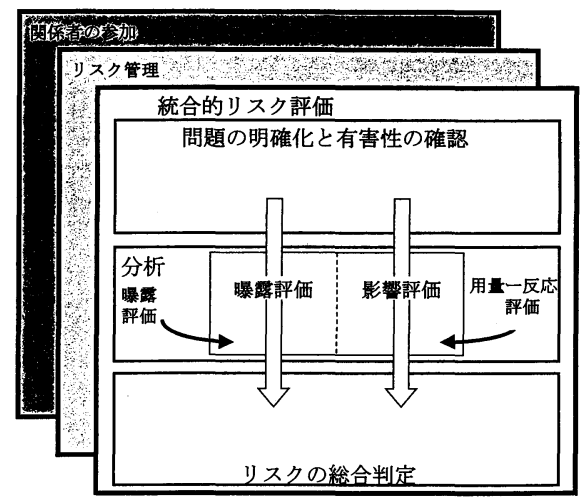

表 1 統合的リスク評価の提案と統合すべき内容

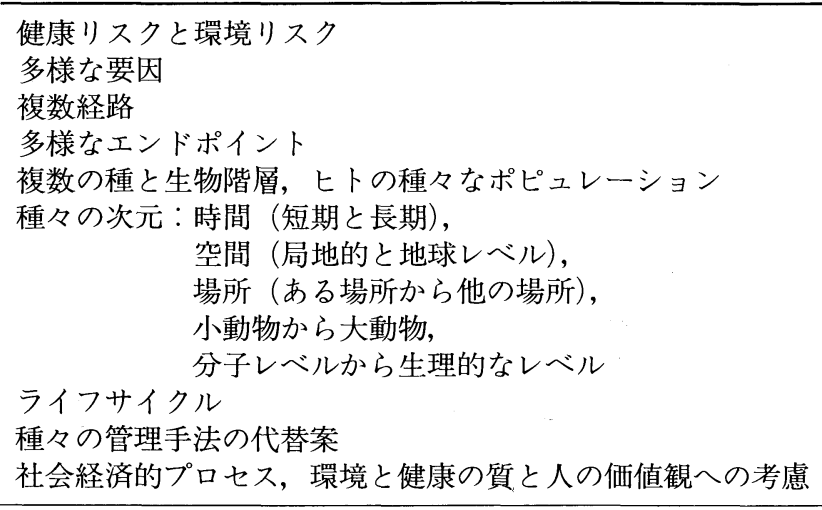

ていない可能性も踏まえて導入的な話しをした上で，応用例の 紹介をしたため時間が限られており十分研究成果を展開できな かった。

金博士は，韓国における環境影響，健康影響評価の研究は開 始してまだ間がないとした上で，韓国では農薬原体と製剤の登 録が環境省と農林省に分かれているという現状を紹介した。つ いで韓国でのカプタホルの健康影響評価と，韓国には新規に登 録された農薬の環境影響評価の例を，従来の評価手法により主 として曝露評価に重点をおいて紹介した.

Mayes 博士はクロルピリフォスの陸棲生物と水棲生物へのリ スクが初期予測に基づくと高く推定されたが，より精密な曝露 予測の結果によるとリスクはそれほど高くないと推定され，水 圈メソコスムを使った試験と野外調査の結果は，後者の推定を 支持するものであったと報告した。

Giddings 博士はピレスロイド農薬の一種シペルメトリンに ついて，魚類と無脊椎動物への影響評価を行った．綿花栽培地 帯の衛星を用いた景観分析によるミシシッピー州 Yazoo 群で のオンサイトの農薬の動態, 分布予測は従来の予測シナリオに 比較して，より精密な情報を提供した。本予測の結果によれば シペルメトリンはこの地域では生態系に大きなリスクをもたら さないであろうと推測された。

Hart 博士は果樹園での農薬処理済みの種子と, 農薬散布の影 響を幾種かの鳥類について調べた結果を報告した。

\section{Environmental Chemistry/Residue Analysis}

このセッションでは, 日本, 韓国, 米国, カナダの 6 名によ ク農薬の大気中への移行を介した環境污染 (2 題), 土壌および 作物における残留分析法 (各 1 題), ならびに酵素免疫測定法 (ELISA) の開発と環境モニタリングへの適用 (2 題) に関する 招待講演がなされた。

\section{農薬挙動}

揮散等により大気中に移行した残留農薬は, ガス交換などの 乾式過程および降雨, 降雪, 霧などの湿式過程の両過程で地表 
に降下する，我が国でも大気中残留農薬の降雨による沈着の研 究は進んでいるが, 山岳地帯の污染や霧による影響についての 研究例は少ない. J. N. Seiber (米国農務省西部地域研究セン タ一）は環境中残留物の大気中移動・沈着，および生態系への インパクトと題して，アリゾナ大学在職中に行ったシェラネバ 名山岳地帯の農薬污染に関する研究を報告し, 大気中農薬によ る山岳部污染における霧の役割を強調した。.カルフォルニア湾 から流入する湿った気流はカルフォルニア州の主農業地域であ るセントラルバレーを越えたのちシェラネバダ山脈に遮られ， 降雨, 降雪, 霧を生じ, 農業地带から大気中に移行した農薬が この過程で山岳地帯を污染する. シェラネバダ山岳地帯での各 種有機塩素剂, 有機リン剂, 殺菌剤の気中濃度の長期にわたる 調査から，ダイアジノン等の有機リン剂が 12 月〜 1 月に最も高 濃度 $\left(200 \sim 300 \mathrm{pg} / \mathrm{m}^{3}\right)$ で検出されること, およびエチルパラチ オンは使用禁止後も高濃度で検出されることが示された.また, 霧中濃度は大気中濃度や樹木葉中の濃度よりも高く, 霧による 沈着とこれによる污染の重要性が指摘された。污染は野生生物 にも及んでおり，肢抢よび羽根の洗液を分析して一日暴露量の 見積をした鷹の例では, 肢洗液における残留濃度が大気, 樹木 葉も含め, 最も高かった。 さらに夕ホ湖水等の残留有機リン剂 の分析により $1920 \mathrm{~m}$ の高地の湖においてもパラチオン等が主 に雪，霧などウェットデポジションによって污染されているこ と, 松葉中のクロルピリホス残留物はオクソン体が主体である こと, 湖のカエルの污染については, クロロタロニルが主な残 留物であることが報告された。

T. F. Bidleman（カナダ大気環境サービス）は, 光学分割に よる環境中残留農薬の追跡と題して, 光学異性体比の環境中で の変化と移行という興味深い講演をした. 光学活性体のエナン チオマー比 (ER；(+)エナンチオマー/(一)エナンチオマー) は, 物理的移動ならびに非生物反応では変化しないが, 水中や 土壤中の微生物による酵素反応では光学異性体の一方が選択的 に代謝され, 変化する. 講演では米国およびカナダ各地の大気, 土壤, 湖水, ならびに北極圈の海水と大気中におけるo, $\mathrm{p}^{\prime}$ DDT, ヘプタクロールエポキシド(HEPX), クロルデン, $\alpha$-へ キサクロロシクロへキサン $(\alpha-\mathrm{HCH})$ の GC/MSによる ER 分 析結果が報告され, ER の変化に地域差のあること,および ER が生分解や選択的蓄積ならびに当該化合物の由来と履歴を探る 上での指標になることが指摘された。

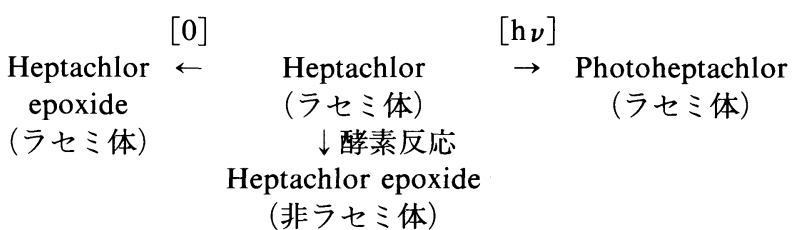

HEPX : スペリオ湖, オンタリオ湖, アラバマ州, サウスカロラ イナ州, 北極海の大気中 HEPX に関する ER は 1.5 2.3で, 農 業地帯で最も低く, 北極海で最も高かった。 大気中で(十)エナ チオマーの方が高比率であったことについて，イリノイ州土壤 中とその表面空気中で(+)エナンチオマー体の割合が圧倒的に 高いことから, 土壤微生物による選択的な代謝が主な原因とさ れた，クロルデンについてはトランス体とシス体に分けて，八 ワイ, ブリテッィシュコロンビア, アラバマ, 中西部コーンベ
ルト地带の大気, 土壌表層空気, 室内空気が調査された. ER が ほぼ 1.0 であった室内空気を除いて，大気中 ER はトランス体 とシス体で逆の傾向を示し，トランス体では＜1, シス体では > 1 であった. コーンベルト地带, 次いでアラバマ州の ER がシス 体，トランス体とも 1.0 から最も大きくずれていた.アラバマ州 とコーンベルト地帯の土䁃中トランス体とシス体の ER 分析結 果 (トランス体約 $0.7 \sim 0.9$, シス体約 1.1 1.2) から，コーンベ ルト地帯で使用された土㙵中残留クロルデンがオンタリオ湖や スペリオ湖上空大気中のクロルデンの主な発生源とされた。 $\alpha$ $\underline{\mathrm{HCH}}$ : オンタリオ湖の湖水および大気中 $\alpha-\mathrm{HCH} の \mathrm{ER}$ 0.85 (湖水) $~ 0.99$ で, 大気中 ER は夏に最も低く, 冬〜春が 1 に 最も近く, フガシティ一比（大きい程大気に分布，小さいほど 大気から水系に沈着）ならびに気中濃度とは負の相間関係に あった. 北極海大気中の $\alpha-\mathrm{HCH}$ 濃度は, 世界的な $\mathrm{HCH}$ 使用量 の減少に伴って低下しており（1992 94 年で 1982 年の約 1/9, $1986 \sim 88$ 年の約 $\left.1 / 4 ; 100 \mathrm{pg} / \mathrm{m}^{3}\right)$, 北極海西部においては 1986 88 年は大気中から水中に沈着する方が優勢であったが, 1992 94 年には水中から大気中に拡散する方が優勢となった. 北極圈の表層海水中の濃度は $0.4 \sim 5.0 \mathrm{ng} / l$ の幅があり, バレン ツ海, ノルウェ一海で低く，ボーフォート海やクウィーンエリ ザべス海で高い $(4 \sim 5 \mathrm{ng} / l)$. 北極海表層海水中 $\mathrm{ER}$ は 0.7 0.94 であり，北極海海水中の微生物分解によって $(+)$ エナンチオ マーが特異的に分解されることが示された。また，表層から 800 $\mathrm{m}$ までの水深では梁いほど ER は低かった。北極海における $\alpha-\mathrm{HCH}$ の微生物分解速度が ER $(400 \sim 600 \mathrm{~m}$ 深度で約 0.3$)$ と 同水域の水収支,ならびに次の設定を基に推定された；(1)400 $600 \mathrm{~m}$ 深度の水は 18 年前の表層水である (1992), (2) 1979 年時 点の表層水中の $\alpha-\mathrm{HCH}$ 濃度は $1.3 \mathrm{ng} / l$ (1992)，(3)今日の 400 $\sim 600 \mathrm{~m}$ 水中濃度は $0.4 \mathrm{ng} / l$ (1996), (4)消失分は分解による, (5)流入時の $\alpha-\mathrm{HCH}$ はラセミ体である: $\alpha-\mathrm{HCH}$ エナンチオ マーの海水中での微生物分解速度定数は，(+)エナンチオマー が $0.12 \mathrm{y}^{-1},(-)$ エナンチオマーが $0.030 \mathrm{y}^{-1}$ と算定された.この 分解速度は海水中の塩基加水分解速度 $\left(k_{\mathrm{h}}=0.011 \mathrm{y}^{-1}\right)$ の $3 \sim 10$ 倍であり, 微生物分解が北極海における $\mathrm{HCH}$ の長期的消失要 因であることが指摘された。

\section{残留分析法}

K. S. Lee と J. W. Kwon（韓国 Chungnam 国立大学）は，韓 国土壌におけるパラコートの効率的抽出法とその評価と題し て, 韓国におけるパラコートの土㙵中における残留実態と分析 法の改良について講演した. (1)残留実態：韓国ではパラコート の使用は 1995 年に一旦禁止されたが, その後, 再び使用が認め られている。しかしながら，その使用面積は許可使用面積の約 3 倍に達しており, パラコートの韓国戋場での土壤中半減期 （118３47 日）が規制基準（180 日）を超えていることと相俟っ て, 最近では土㙵残留レベルが $30 \mathrm{ppm}$ を超える例も出るなど 憂慮すべき実態となっている. (2)分析法改良：従来の土壤分析 法 (9M 硫酸抽出, 中和後 5\%EDTA-Na 添加, イオン交換樹脂 カラムクロマトグラフィーによる精製）に，濃塩酸洗浄による 前処理 (1.5 時間) と抽出液の過酸化水素处理 0.5 時間を加える ことにより, 抽出溶媒使用量が低減 $(1 l \rightarrow 0.3 l)$ でき, 回収率 も向上 (84 97\%) するほか, 抽出時間が大幅（1/5）に短縮で 
きることを報告した，残された問題として，パラコートの土壤 中残留分析法の検出感度が 1960 年代から今日まで $0.01 \mathrm{mg} / \mathrm{kg}$ でほとんど向上しておらず，キャピラリーゾーン電気泳動法が 期待されると指摘した。

斎藤（愛知県衛生研究所）は, ゲル濾過クロマトグラフィー (GPC)を用いた農薬残留分析と題して, 我が国における農薬の 食品中残留基準の設定および告示分析法の整備が進んでいるこ とを報告するとともに残留分析における GPC の有用性を概説 した. また, 多成分同時分析における GPCの利用について玄米 におけるフェノブカルブ，イナベンフィド，フサライドの分析 を例にとり, 精製と分離のすべてを GPC で行うのではなく, 検 出法の特異性を勘案して利用することが肝要であり, GPCで分 画化した試料はシリカゲルミニカラムで精製すれば，フェノブ カルブは GC/NPD，イナベンフィドはHPLC，フサライドは $\mathrm{GC} / \mathrm{ECD}$ で直接，定量分析できることを報告した。 CDFA 法による抽出

（代替品アセトンまたはへキサンをジクロロメタンの 代替品にして抽出)

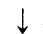

GPC（Shodex EV2000; 20\%アセトンノシクロヘキサン）$$
\downarrow
$$$$
\text { シリカゲルミニカラム }
$$

\section{ELISA}

三宅 (ヤトロン株式会社) は，水田除草骫定量用 ELISA の開 発と題して, ELISA 法を概説するとともに, ベンスルフロンメ チル,ピラゾスルフロンエチル, チオベンカルブのモノクロナー 儿抗体による直接競合 ELISA（直接 C-ELISA）の開発と，環境 水（田面水，河川水，湖沼水）残留分析への適用結果を発表し
た。検出感度は 3 化合物とも $0.2 \mathrm{ng} / \mathrm{ml}$ であり，C-ELISAによ る分析結果は HPLC, GCによる分析結果とよく一致した。 ま た，上記 3 種のモノクロナール抗体の特異性が高いことを利用 して 3 種抗体を混合した直接 C-ELISA を開発し, 同法で 3 農 薬を効率よく同時定量できることを示した. 今後さらに，40種 以上の農薬の ELISA 系を開発する予定であると述べた。

Qing Li (ハワイ大学) は, 環境分析における免疫化学測定と 題して，ハワイ州の地下水污染に関し，サトウキビおよびパイ ナップル畑で使用される除草剤に注目し，オアフ，カウアイ， マウイ，八ワイ島の農業用井戸と家庭用井戸から採取した井水 中のアトラジンとアメトリンを ELISA と GC-MS で測定した 結果を報告した。両法による測定値はほぼ一致していた。また, 多環芳香属炭化水素類 (PAHs) のモノクロナ一ル抗体 （mAb10C10）による ELISA 系を作成し，オアフ島の野生生物 保護区内の地表水および底質を ELISA と GC/MS 法で分析し た。一般に ELISA は GC/MS 等よりもやや高めの測定值を与 えるが, ELISA によるトータル PAHs としての検出値はそれを 明らかに超え, 全試料とも $\mathrm{GC} / \mathrm{MS}$ 法の 1.5 倍程度であった。 こ の分析では試料を超臨界抽出法で抽出しており, EDTA-4Naを 添加して1-ヒドロキシピレンなど水酸化 PAHs の抽出効率を 20〜30\%上げている. 試料中に 1-七ドロキシピレンも存在して いることが HPLC で確認されたことから, 試料中には恐らく他 の水酸化 PAHs も存在しており, mAb10C10 がそれらとも反応 して GC/MSよりも高濃度で検出されたのであろうと示唆さ れた。 また，同抗体のアミノ酸配列を明らかにして立体構造を 解析し, PAHs の結合部位がリジンとアルギニンであることを 示した. 